\title{
Spatial distribution and environmental factors of catchment-scale soil heavy metal contamination in the dry-hot valley of Upper Red River in southwestern China
}

\author{
Xingwu Duan $^{\mathrm{a}, \mathrm{b}, *}$, Guangli Zhang ${ }^{\mathrm{b}}$, Li Rong a,b ${ }^{\mathrm{a}}$, Haiyan Fang ${ }^{\mathrm{c}}$, Daming He ${ }^{\mathrm{a}, \mathrm{b}}$, Detai Feng ${ }^{\mathrm{b}}$ \\ a Yunnan Key Laboratory of International Rivers and Trans-boundary Eco-security, Kunming 650091, PR China \\ b Institute of International Rivers and Eco-security, Yunnan University, Kunming 650091, PR China \\ ${ }^{\mathrm{c}}$ Key Laboratory of Water Cycle and Related Land Surface Processes, Institute of Geographic Sciences and Natural Resources Research, Chinese Academy of Sciences, Beijing 100101, PR China
}

\section{A R T I C L E I N F O}

\section{Article history:}

Received 27 October 2014

Received in revised form 7 July 2015

Accepted 13 July 2015

Available online 27 July 2015

\section{Keywords:}

Heavy metal contamination

Spatial distribution

Environmental control factors

Dry-hot valley

Hydropower exploitation

\begin{abstract}
A B S T R A C T
The severe soil erosion in the dry-hot valley (DHV) in southwestern China may result in heavy metal pollution in the Red River. However, little is known concerning the level of contamination, spatial distribution and environmental controls of the heavy metals in the soils of the DHV. Heavy metal concentrations in agricultural soils in a typical DHV catchment were investigated. Soil samples from both the topsoil $(0-20 \mathrm{~cm})$ and subsoil $(20-40 \mathrm{~cm})$ were collected at sixty-two sites, and the soil physical and chemical properties of sand, silt, clay, and organic matter contents; soil pH; bulk density; and the concentrations of $\mathrm{Cr}, \mathrm{Ni}, \mathrm{Cu}, \mathrm{Zn}$, and $\mathrm{Pb}$ were determined. Topographic factors of slope gradient, slope aspect, elevation, and topographic wetness index at each site were calculated using DEM. Kriging and canonical correspondence analyses were used to assess the spatial distribution of and environmental controls on heavy metals. The results demonstrated that the concentrations of $\mathrm{Cr}, \mathrm{Ni}, \mathrm{Cu}, \mathrm{Zn}, \mathrm{and} \mathrm{Pb}$ in the DHV were higher than most of the reported values for agricultural soils worldwide and that the DHV may constitute a potential source of heavy metal pollution in the Red River. Considering each heavy metal individually, the vertical distribution in the topsoil and subsoil was similar at all of the sampling sites. High concentrations of $\mathrm{Cr}$, Ni, $\mathrm{Zn}$ and $\mathrm{Pb}$ were observed at low elevations and low slope areas, and the spatial distribution pattern of $\mathrm{Cu}$ was contrary to that of $\mathrm{Cr}, \mathrm{Ni}, \mathrm{Zn}$ and $\mathrm{Pb}$. The concentrations of heavy metals in the topsoil were controlled by both soil and topographical factors, while in the subsoil, they were primarily controlled by soil-related factors. It is concluded that high background concentrations, uncontrolled use of chemical fertilizers, and mining are the sources responsible for heavy metal contamination in the DHV region.
\end{abstract}

(c) 2015 Elsevier B.V. All rights reserved.

\section{Introduction}

Soils are a key component of the terrestrial ecosystem and play a key role in food production, biochemical transformations, the cycling of elements and many recreational activities (Morgan, 2009). Due to rapid industrialization and urbanization during recent decades (Kelepertzis, 2014; Sun et al., 2010), some soils have become contaminated by heavy metals accumulated from sources such as vehicle emissions, industrial wastes, mine tailings, and the application of fertilizers and sewage sludge (Wuana and Okieimen, 2011). As a result, heavy metal contamination in soils has become an important environmental issue in recent years (Fu et al., 2014; Micó et al., 2006).

Heavy metal contamination in soils exhibits specific pollutant characteristics. Heavy metals do not decay over time and can be toxic to plants when they exceed specific thresholds. Heavy metals are present

\footnotetext{
* Corresponding author at: Yunnan Key Laboratory of International Rivers and Transboundary Eco-security, Kunming 650091, PR China.

E-mail address: xwduan@ynu.edu.cn (X. Duan).
}

in soils at background levels from non-anthropogenic origins and can become mobile as a result of changing environmental conditions or saturation beyond the buffering capacity of soils (Facchinelli et al., 2001).

Accumulation of heavy metals in soils has the potential to inhibit soil functioning, cause toxicity to plants, contaminate the food chain, and promote heavy metal transfer to humans (He et al., 2005). Overland flow and soil erosion are increasingly recognized as important in the transfer of heavy metals from soils to surface waters. Thus, heavy metal contamination can not only affect soil ecology, agricultural production, and underground quality but also influence aquatic ecosystems and cause deformation in fish (Heredia and Cirelli, 2009).

Agricultural production plays a key role in the development of China. However, with rapid industrialization, urbanization, and increasing reliance on agrochemicals, heavy metal contamination in soils has become severe during the last two decades (Pan and Wang, 2012; Wong et al., 2002). A recent study reported that more than $16 \%$ of Chinese agricultural soils are contaminated with heavy metals (Song et al., 2013). Heavy metal contamination and the restoration of soils in China have been the subject of much attention and were important components 
in the National "12th Five-Year Plan" for environmental protection (Kelepertzis, 2014; The State Council of the People's Republic of China, 2012). In the past decade, numerous studies have been reported on the concentrations, distribution, and sources of heavy metals in Chinese soils (Shao et al., 2014; Song et al., 2013). However, most of those studies focused on urban soils (Li et al., 2013; Shao et al., 2014), and only a few addressed contamination in the agricultural soils of the dry-hot valley (DHV) region, an ecologically fragile zone with severe soil erosion in China (Zhang, 1992).

The DHV region is characterized by high temperatures (the annual mean temperature is $>20^{\circ} \mathrm{C}$ ) and low humidity (the annual mean precipitation is $<650 \mathrm{~mm}$ ) (Wang et al., 2004). The total area of the DHV is approximately $3.2 \times 10^{4} \mathrm{~km}^{2}$, with the largest proportion distributed in the deeply incised valleys of the Upper Red River (Fig. 1) (Ji et al., 2009; Zhang, 1992). The soils in this area have high geological background values of heavy metals (Ministry of Environmental Protection of the People's Republic of China, 1990). According to the national survey of soil elements, in this region, the background values of $\mathrm{Pb}$ are 1.58 -fold and of $\mathrm{Cu}$ are 1.44 -fold higher than the national average. Severe soil erosion caused by high sand content in the soils and steep slopes in the DHV (Yang et al., 2003) may contribute to heavy metal pollution in the river system (Cenci and Martin, 2004; Fu et al., 2012) because of increased sediment loads (He et al., 2007; Le et al., 2007; Miao et al.,
2010). Furthermore, hydropower exploitation via the proposed cascade reservoir system in the Upper Red River (Zhai et al., 2007) may submerge parts of the DHV, making this region a potential source of heavy metal pollution in downstream agricultural products, fisheries, and river ecosystems (Phan et al., 2013; Steininger, 2003). However, little is known about the levels of contamination, spatial distribution patterns and sources of heavy metals in the agricultural soils of the DHV.

In this study, the heavy metals in the soils of a typical agricultural catchment in the DHV were studied. Our objectives were to (1) assess heavy metal concentrations, (2) characterize the spatial distribution of heavy metals, and (3) evaluate the impact of environmental factors on soil heavy metals.

\section{Materials and methods}

\subsection{Study area}

The study area was located in the Laozhai catchment on the right bank of the Yunjiang River DHV (Fig. 1) in southwestern China. The Yunjiang River, which is also known as the Red River, flows through China, Laos, and Vietnam. The river originates in the Yunnan Province, southwestern China, where it is called Yuanjiang. The Yunjiang DHV is the most concentrated and continuous DHV in China (Zhang, 1992). The area of the
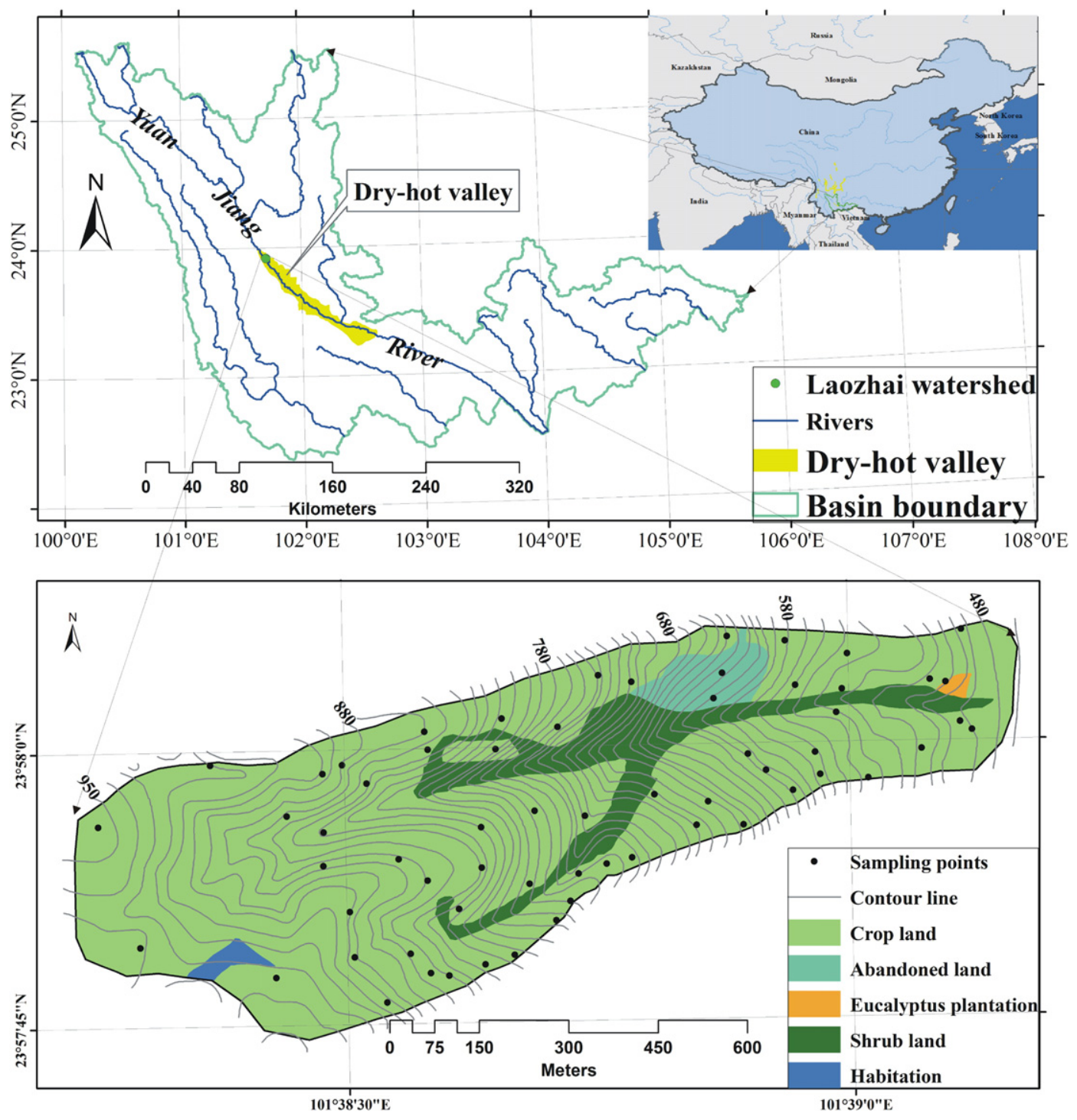

Fig. 1. Study area and spatial distribution of soil sampling sites. 
Laozhai catchment is $0.57 \mathrm{~km}^{2}$, more than $85.00 \%$ of which is farmland with the primary crops of corn or sugarcane in summer and autumn; the area lies fallow in winter and spring. The average elevation is $768.00 \mathrm{~m}$ (ranging from 470.00 to $950.00 \mathrm{~m}$ ), and the average slope is $23.64^{\circ}$. The local climate is characterized by sufficient heat flux, high accumulated temperature, hot summers, and warm winters. The torrid red soils are widely distributed in this area and characterized by a thin profile, high sand or stone content, poor water retention, and few available nutrients (National Soil Survey Office, 1998). The most common vegetation type is tropical bushveld with a sparse presence of trees. Dominant species are Heteropogon contortus and Dodonaea riscosa (Zhang, 1992).

\subsection{Sample collection and analysis}

Sixty-two sites were selected to monitor soil heavy metals in the Laozhai catchment, and each site was selected after careful inspection the representativeness of the agricultural land and the topographical positions in the DHV. Undisturbed and disturbed soil samples were collected separately at each sampling point in both topsoil $(0-20 \mathrm{~cm})$ and subsoil $(20-40 \mathrm{~cm})$ in July 2012 . The undisturbed samples were collected with a soil core (with a diameter of $55.00 \mathrm{~mm}$ and a height of $50.00 \mathrm{~mm}$ ), and three undisturbed samples were collected at each site; the undisturbed samples were used to measure soil bulk density. The disturbed soil samples were air-dried at room temperature and sieved through a $2.00-\mathrm{mm}$ nylon sieve. The particle size distribution, organic matter content $(\mathrm{OM}), \mathrm{pH}$, and bulk density (BD) of all samples were determined in the laboratory following the methods of the National Soil Analysis Standards (Liu, 1996). Briefly, particle size distribution (sand $(0.02-2.00 \mathrm{~mm})$, silt $(0.002-0.02 \mathrm{~mm})$, and clay $(<0.002 \mathrm{~mm})$ ) were determined with the pipette method after $\mathrm{H}_{2} \mathrm{O}_{2}$ treatment to remove organic matter. Organic matter content was measured using the combustion method after passing the soil samples through a $0.15-\mathrm{mm}$ sieve. Bulk density was measured with the cutting-ring method, and $\mathrm{pH}$ was determined using the potential method (the soil water ratio was 2.5:1). The concentrations of $\mathrm{Cr}, \mathrm{Ni}, \mathrm{Cu}, \mathrm{Zn}$, and $\mathrm{Pb}$ were determined by X-ray fluorescence spectrometry (XRF, ZSX100e, Rigaku Corporation, Japan). Soil samples were homogenized and sieved to 200-mesh grain size, pressed into powder pellets (diameter $32.00 \mathrm{~mm}$, height $4.00 \mathrm{~mm}$ and weight $4.00 \mathrm{~g}$ ), added to alumina cups and pressed under 40-ton pressure for $20.00 \mathrm{~s}$ (Tan et al., 2012). X-ray counts were converted into concentrations using a computer program based on the fundamental parameter method (Kitov, 2000; Sherman, 1956). The sensitivity of the analysis was established, and all determined elements $(\mathrm{Cr}, \mathrm{Ni}, \mathrm{Cu}, \mathrm{Zn}$, and $\mathrm{Pb}$ ) exceeded the lower detection limit and were adequate for determination. The accuracy of the analytical method was estimated by calculating the relative systematic error between the determined and recommended values of the geological standard materials: (GBW(E)070008, GBW(E)070009, and GBW(E)0700010 geochemical reference materials, obtained from the National Certified Materials Resources Network). The mean relative systematic error was less than $12.00 \%$ compared to the recommended values. Analytical duplicates comprising $20 \%$ of the total samples were also analyzed to test the precision of the results; if the precision for a particular element exceeded $10.00 \%$ at the $95.00 \%$ confidence level, the concentrations of $\mathrm{Cr}, \mathrm{Ni}, \mathrm{Cu}, \mathrm{Zn}$, and $\mathrm{Pb}$ in the soil sample were re-determined.

\subsection{Contamination factor}

The contamination factor (CF) was used as a measure of metal pollution in soils, as given by Hakanson (1980). The CF was obtained using Eq. (1) at each sample site:

$C F_{i j}=C_{i j} / S_{j}$

where $C F_{i j}$ is the contamination factor in the $i$ th sample of the $j$ th heavy metal, $C_{i j}$ is the concentration of the $j$ th heavy metal at the $i$ th sampling point, and $S_{j}$ is the natural background concentration of the $j$ th heavy metal. The geochemical background values were based on the environmental background concentrations of the torrid red soil in China (Ministry of Environmental Protection of the People's Republic of China, 1990) and were (all values in $\mathrm{mg} \cdot \mathrm{kg}^{-1}$ ) 45.00 for $\mathrm{Cr}, 32.50$ for $\mathrm{Cu}, 24.40$ for $\mathrm{Ni}, 62.50$ for $\mathrm{Zn}$, and 41.20 for $\mathrm{Pb}$. $\mathrm{CF}$ values were interpreted as follows: low contamination at $\mathrm{CF}<1.00$, moderate contamination at $1.00 \leq \mathrm{CF}<3.00$, considerable contamination at $3.00 \leq \mathrm{CF}<6.00$, and very high contamination at $\mathrm{CF} \geq 6.00$, according to Fujita et al. (2014).

\subsection{Calculation of topographic factors}

The topographic factors of elevation above sea level (El), slope gradient $(\mathrm{Sl})$, and slope aspect ( $\mathrm{Sa}$ ) at each sample position were estimated from the $5 \mathrm{~m}$-DEM, built from the 1:10,000 digital topographic map and processed using ArcGis software. We used the soil wetness index (SWI), which is considered to be an effective indicator of those landscape positions in which overland flow dominates water transport processes. Therefore, SWI may exhibit a significant relationship with soil water content, soil organic carbon content, and other soil physicochemical properties (Pei et al., 2010; Sumfleth and Duttmann, 2008). The SWI was calculated using the specific catchment area $\left(A_{s}\right)$ and slope gradient as independent variables $(\beta)$, both of which were obtained from the DEM (Wilson and Gallant, 2000):

$\mathrm{SWI}=\ln \left(\frac{A_{S}}{\tan \beta}\right)$

\subsection{Spatial and statistical analyses}

Ordinary kriging in ArcGis V9.3 was used to estimate the spatial components of the soil heavy metal concentrations. If the original variables (heavy metals) showed skewed distributions, logit transformations were used to make the data suitable for regression and variogram analyses (Martín et al., 2006). Semivariograms were developed to establish the degree of spatial continuity of the heavy metal concentrations. Three parameters, including nugget, sill, and range, were used to describe the semivariogram. The ordinary kriging framework used in this paper follows that previously described in Zimmerman and Zimmerman (1991). For a more in-depth explanation of the procedures, see Cressie (1988).

When the criterion of normal distribution of soil heavy metal concentration, soil physico-chemical properties and environmental factors was satisfied, Box-Cox transformation (Sakia, 1992) was used for the statistical analysis of non-normal distributions. Pearson correlation analysis was used to identify the relationships between the concentrations of heavy metals and environmental factors. The differences in heavy metal and soil properties between topsoil and subsoil were tested by analysis of variance (ANOVA). Differences were considered significant when $\mathrm{P}<0.05$. The basic descriptive statistics, correlation analysis, and ANOVA were performed using SPSS 16.0 (SPSS München, Germany). In addition, to determine the relative importance of environmental factors in explaining the concentrations of heavy metals in the Laozhai watershed, canonical correspondence analysis (CCA) was used. CCA is a multivariate method to elucidate the relationships between response variables and their environmental effect factors. The method was designed to extract synthetic environmental gradients from ecological data-sets, and the primary method used to present the results of CCA is the ordination diagram. The relative importance of environmental factors in explaining the response variables can be unscrambled by the length of the environmental factors and the arrows between environmental factors and the response variables in the ordination diagram; for a more in-depth explanation of the ordination diagram, see Lepš and Šmilauer (2003). CCA analysis has been widely 
Table 1

General statistics of terrain factors $(n=62)$.

\begin{tabular}{lllrrrrrr}
\hline $\begin{array}{l}\text { Terrain } \\
\text { factors }\end{array}$ & Dis. & Min & Max & Mean & Std. D & Median & Skewness & Kurtosis \\
\hline Sa $\left({ }^{\circ}\right)$ & $\mathrm{N}$ & 0.87 & 346.46 & 81.98 & 65.53 & 70.69 & 1.83 & 5.69 \\
Sl $\left({ }^{\circ}\right)$ & $\mathrm{N}$ & 0.00 & 50.44 & 25.83 & 11.41 & 26.99 & -0.46 & 0.52 \\
$\mathrm{El}(\mathrm{m})$ & $\mathrm{B}-\mathrm{C}$ & 490.34 & 950.00 & 737.77 & 142.29 & 772.80 & -0.36 & -1.30 \\
SWI & $\mathrm{B}-\mathrm{C}$ & 8.09 & 34.91 & 13.36 & 5.55 & 12.03 & 2.74 & 6.99 \\
\hline
\end{tabular}

Dis.: distribution (N: normal and B-C: Box-Cox transformation), Min: minimum, Max: maximum, and Std. D: standard deviation.

used to study the environmental control over concentrations of soil heavy metals (Beasley and Kneale, 2003; Read et al., 1998). In this study, the heavy metal concentrations of each monitor site were set as response variables, and the environmental factors of El, Sa, Sl, SWI, $\mathrm{OM}$ and $\mathrm{pH}$ were set as independent variables. CCA analysis was conducted using Canoco software 4.5 (Microcomputer Power, Ithaca, NY, USA).

\section{Results}

\subsection{Environmental factors}

The median Sa was $70.69^{\circ}$, indicating that the main slope aspect of the sampled positions was East by North. The median Sl was $26.99^{\circ}$, with a maximum of $50.44^{\circ}$. The SWI ranged from 8.09 to 34.91 , with a median value of 12.03 (Table 1 ).

The torrid red soil was characterized by a high sand content and acidic conditions in the study area. There were no significant differences in the sand, silt, clay and pH between the topsoil and subsoil, while the OM content and BD of the topsoil were significantly higher than those of the subsoil, probably because of soil erosion and cultivation (Table 2).

\subsection{Heavy metal contamination}

The concentrations of heavy metals (both mean and median values) in both $0-20 \mathrm{~cm}$ and $20-40 \mathrm{~cm}$ of soil depth were in the order (from highest to lowest) $\mathrm{Zn}>\mathrm{Cu}>\mathrm{Cr}>\mathrm{Ni}>\mathrm{Pb}$. The largest variation in mean values was observed for $\mathrm{Zn}$ (Table 3 ). The concentrations of $\mathrm{Pb}$ in subsoil were significantly higher than those in topsoil. However, although the concentrations of $\mathrm{Cr}, \mathrm{Ni}$, and $\mathrm{Cu}$ in subsoil were also higher than in topsoil, these differences were not significant (Table 3). Additionally, the median concentrations of $\mathrm{Zn}$ in topsoil were slightly higher than those in subsoil.

$\mathrm{Cu}$ had the highest contamination factor in both topsoil and subsoil, followed by $\mathrm{Ni}, \mathrm{Zn}$, and $\mathrm{Cr}$. Pb had the lowest $\mathrm{CF}$ values (Table 3). More than $50.00 \%$ of the samples belonged to the "considerable contamination" level for $\mathrm{Cu}$ in both topsoil and subsoil. More than $30.00 \%$ of the samples in topsoil and more than $43.00 \%$ of the samples in subsoil fell within the "very high contamination" level (Fig. 2). The "considerable contamination" level was observed for $\mathrm{Ni}$ in approximately $70.00 \%$, for

Table 2

General statistics of soil physicochemical properties $(n=62)$.

\begin{tabular}{|c|c|c|c|c|c|c|c|c|c|c|}
\hline $\begin{array}{l}\text { Soil physicochemical } \\
\text { properties }\end{array}$ & Soil layers & Dis. & Min & Max & Mean & Median & Std. D & Skewness & Kurtosis & Sig. \\
\hline \multirow[t]{2}{*}{ Sand $\left(\mathrm{g} \cdot 100 \mathrm{~g}^{-1}\right)$} & $0-20 \mathrm{~cm}$ & $\mathrm{~N}$ & 17.45 & 61.50 & 39.00 & 37.42 & 9.81 & 0.24 & -0.07 & 0.26 \\
\hline & $20-40 \mathrm{~cm}$ & $\mathrm{~B}-\mathrm{C}$ & 16.12 & 84.11 & 36.79 & 33.94 & 11.85 & 1.40 & 3.46 & \\
\hline \multirow[t]{2}{*}{ Silt $\left(g \cdot 100 g^{-1}\right)$} & $0-20 \mathrm{~cm}$ & $\mathrm{~N}$ & 16.44 & 40.72 & 27.21 & 28.00 & 5.75 & 0.05 & -0.51 & 0.69 \\
\hline & $20-40 \mathrm{~cm}$ & $\mathrm{~N}$ & 9.35 & 40.44 & 26.78 & 28.19 & 6.38 & -0.42 & -0.21 & \\
\hline \multirow[t]{2}{*}{ Clay $\left(\mathrm{g} \cdot 100 \mathrm{~g}^{-}\right)$} & $0-20 \mathrm{~cm}$ & $\mathrm{~N}$ & 17.05 & 63.72 & 33.80 & 32.47 & 10.22 & 0.93 & 1.27 & 0.17 \\
\hline & $20-40 \mathrm{~cm}$ & $\mathrm{~N}$ & 6.54 & 67.05 & 36.43 & 37.19 & 11.00 & 0.20 & 1.07 & \\
\hline \multirow[t]{2}{*}{$\mathrm{BD}\left(\mathrm{g} \cdot \mathrm{cm}^{-3}\right)$} & $0-20 \mathrm{~cm}$ & $\mathrm{~N}$ & 0.99 & 1.38 & 1.17 & 1.15 & 0.10 & -0.09 & -0.78 & 0.00 \\
\hline & $20-40 \mathrm{~cm}$ & $\mathrm{~N}$ & 0.91 & 1.55 & 1.25 & 1.24 & 0.12 & -0.04 & 0.62 & \\
\hline \multirow[t]{2}{*}{$\mathrm{pH}$} & $0-20 \mathrm{~cm}$ & $\mathrm{~B}-\mathrm{C}$ & 4.70 & 6.80 & 6.12 & 6.23 & 0.39 & -1.02 & 1.52 & 0.48 \\
\hline & $20-40 \mathrm{~cm}$ & $\mathrm{~N}$ & 4.65 & 6.77 & 6.07 & 6.13 & 0.41 & -0.78 & 0.90 & \\
\hline \multirow[t]{2}{*}{$\mathrm{OM}\left(\mathrm{g} \cdot 100 \mathrm{~g}^{-1}\right)$} & $0-20 \mathrm{~cm}$ & $\mathrm{~B}-\mathrm{C}$ & 1.23 & 9.94 & 2.459 & 23.05 & 1.12 & 4.99 & 3.25 & 0.00 \\
\hline & $20-40 \mathrm{~cm}$ & $\mathrm{~B}-\mathrm{C}$ & 0.74 & 4.41 & 1.89 & 1.64 & 0.71 & 1.23 & 0.18 & \\
\hline
\end{tabular}

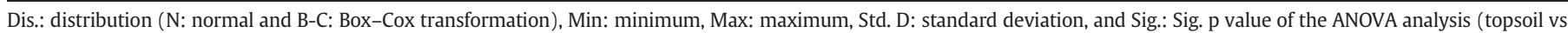
subsoil).

Table 3

General statistics of heavy metal concentration and contamination $(n=62)$.

\begin{tabular}{|c|c|c|c|c|c|c|c|c|c|c|}
\hline Factors & Soil layers & Dis. & Min & Max & Mean & Std. D & Median & Skewness & Kurtosis & Sig. \\
\hline \multirow[t]{2}{*}{$\mathrm{Cr}\left(\mathrm{mg} \cdot \mathrm{kg}^{-1}\right)$} & $0-20 \mathrm{~cm}$ & $\mathrm{~N}$ & 42.00 & 339.00 & 166.16 & 61.15 & 166.16 & 0.31 & 0.25 & 0.82 \\
\hline & $20-40 \mathrm{~cm}$ & $\mathrm{~N}$ & 26.00 & 306.00 & 168.81 & 65.32 & 169.50 & 0.11 & -0.33 & \\
\hline \multirow[t]{2}{*}{$\mathrm{Ni}\left(\mathrm{mg} \cdot \mathrm{kg}^{-1}\right)$} & $0-20 \mathrm{~cm}$ & $\mathrm{~N}$ & 40.00 & 168.00 & 108.61 & 26.20 & 107.50 & -0.10 & 0.10 & 0.24 \\
\hline & $20-40 \mathrm{~cm}$ & $\mathrm{~B}-\mathrm{C}$ & 54.00 & 189.00 & 114.34 & 27.64 & 110.50 & 0.35 & 0.25 & \\
\hline \multirow[t]{2}{*}{$\mathrm{Cu}\left(\mathrm{mg} \cdot \mathrm{kg}^{-1}\right)$} & $0-20 \mathrm{~cm}$ & $\mathrm{~B}-\mathrm{C}$ & 46.00 & 460.00 & 193.37 & 83.32 & 173.00 & 1.10 & 1.53 & 0.25 \\
\hline & $20-40 \mathrm{~cm}$ & $\mathrm{~B}-\mathrm{C}$ & 53.00 & 658.00 & 214.21 & 115.59 & 174.50 & 1.86 & 4.18 & \\
\hline \multirow[t]{2}{*}{$\mathrm{Zn}\left(\mathrm{mg} \cdot \mathrm{kg}^{-1}\right)$} & $0-20 \mathrm{~cm}$ & $\mathrm{~B}-\mathrm{C}$ & 34.00 & 852.00 & 266.89 & 182.98 & 226.00 & 1.10 & 1.04 & 0.78 \\
\hline & $20-40 \mathrm{~cm}$ & $\mathrm{~B}-\mathrm{C}$ & 36.00 & 764.00 & 276.29 & 185.31 & 217.00 & 0.78 & -0.20 & \\
\hline \multirow[t]{2}{*}{$\mathrm{Pb}\left(\mathrm{mg} \cdot \mathrm{kg}^{-1}\right)$} & $0-20 \mathrm{~cm}$ & $\mathrm{~B}-\mathrm{C}$ & 23.00 & 173.00 & 66.98 & 26.84 & 61.00 & 1.45 & 3.36 & 0.04 \\
\hline & $20-40 \mathrm{~cm}$ & $\mathrm{~B}-\mathrm{C}$ & 24.00 & 210.00 & 79.97 & 41.48 & 71.00 & 1.53 & 2.03 & \\
\hline \multirow[t]{2}{*}{$\mathrm{CF}-\mathrm{Cr}$} & $0-20 \mathrm{~cm}$ & $\mathrm{~N}$ & 0.93 & 7.53 & 3.69 & 1.36 & 3.60 & 0.31 & 0.25 & 0.82 \\
\hline & $20-40 \mathrm{~cm}$ & $\mathrm{~N}$ & 0.58 & 6.80 & 3.75 & 1.45 & 3.77 & 0.11 & -0.33 & \\
\hline \multirow[t]{2}{*}{$\mathrm{CF}-\mathrm{Ni}$} & $0-20 \mathrm{~cm}$ & $\mathrm{~N}$ & 1.79 & 7.50 & 4.85 & 1.17 & 4.80 & -0.10 & 0.10 & 0.24 \\
\hline & $20-40 \mathrm{~cm}$ & $\mathrm{~B}-\mathrm{C}$ & 2.41 & 8.44 & 5.10 & 1.23 & 4.93 & 0.35 & 0.25 & \\
\hline \multirow[t]{2}{*}{$\mathrm{CF}-\mathrm{Cu}$} & $0-20 \mathrm{~cm}$ & $\mathrm{~B}-\mathrm{C}$ & 1.42 & 14.15 & 5.95 & 2.56 & 5.32 & 1.10 & 1.53 & 0.25 \\
\hline & $20-40 \mathrm{~cm}$ & $\mathrm{~B}-\mathrm{C}$ & 1.63 & 20.25 & 6.59 & 3.56 & 6.37 & 1.86 & 4.18 & \\
\hline \multirow[t]{2}{*}{$\mathrm{CF}-\mathrm{Zn}$} & $0-20 \mathrm{~cm}$ & $\mathrm{~B}-\mathrm{C}$ & 0.54 & 13.63 & 4.27 & 2.93 & 3.62 & 1.10 & 1.04 & 0.78 \\
\hline & $20-40 \mathrm{~cm}$ & $\mathrm{~B}-\mathrm{C}$ & 0.58 & 12.22 & 4.42 & 2.96 & 3.47 & 0.78 & -0.20 & \\
\hline \multirow[t]{2}{*}{$\mathrm{CF}-\mathrm{Pb}$} & $0-20 \mathrm{~cm}$ & $\mathrm{~B}-\mathrm{C}$ & 0.56 & 4.20 & 1.63 & 0.65 & 1.48 & 1.45 & 3.36 & 0.04 \\
\hline & $20-40 \mathrm{~cm}$ & B-C & 0.58 & 5.10 & 1.94 & 1.01 & 1.72 & 1.53 & 2.03 & \\
\hline
\end{tabular}

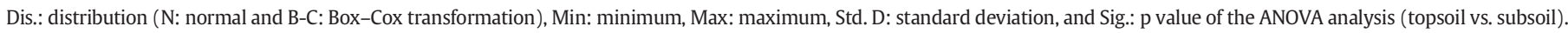



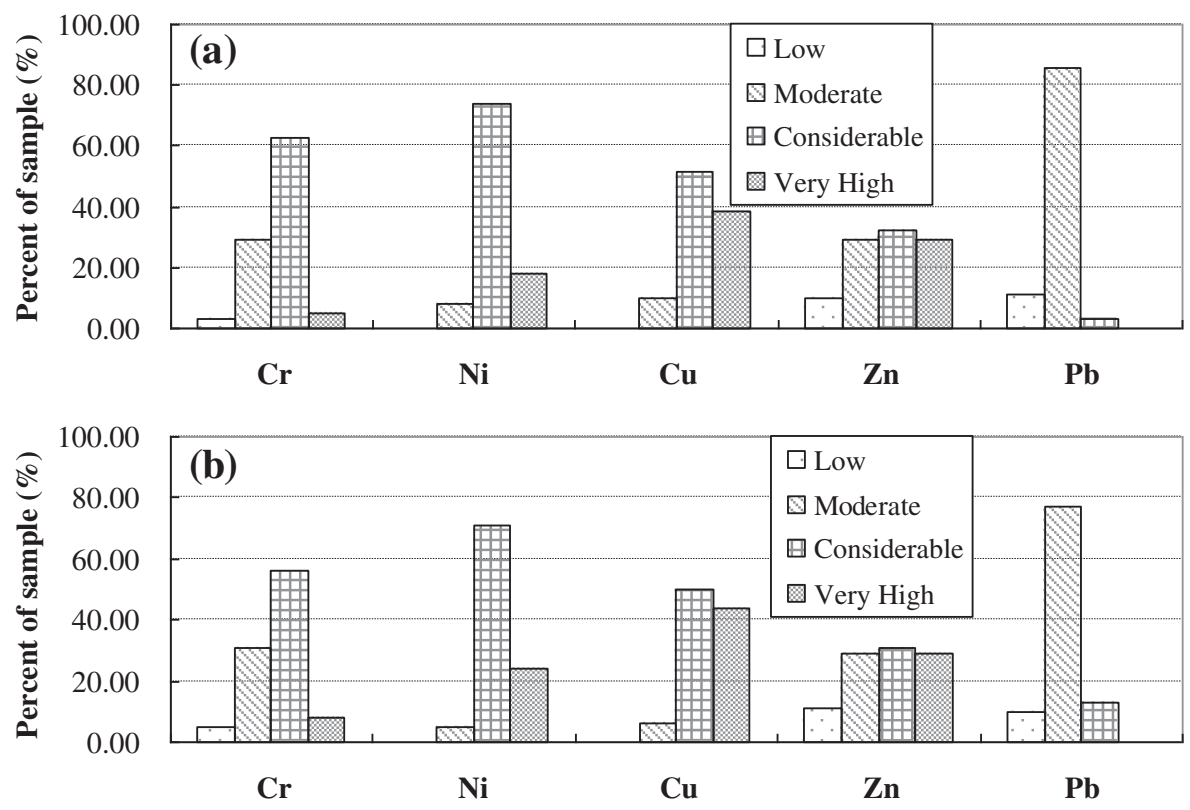

Fig. 2. Sample compositions of different heavy metal contamination levels in topsoil (a) and subsoil (b).

$\mathrm{Cr}$ in $60.00 \%$, and for $\mathrm{Zn}$ in $30.00 \%$ in both topsoil and subsoil. More than $75.00 \%$ of the samples had "moderate contamination" levels and less than $13.00 \%$ of the samples had "considerable contamination" for $\mathrm{Pb}$ in both topsoil and subsoil. As a result, $\mathrm{Cu}$ had the highest contamination level in the study area, followed by $\mathrm{Ni}, \mathrm{Zn}, \mathrm{Cr}$, and $\mathrm{Pb}$.

\subsection{Spatial distribution of heavy metals}

The concentrations of soil $\mathrm{Cr}, \mathrm{Ni}, \mathrm{Cu}, \mathrm{Pb}$ and $\mathrm{Zn}$ under different slope gradients, elevations and slope aspects were analyzed. The distributions of soil heavy metals in topsoil and subsoil were generally similar (Fig. 3), and the distribution of $\mathrm{Cu}$ was different from that of $\mathrm{Cr}, \mathrm{Ni}, \mathrm{Zn}$ and $\mathrm{Pb}$. Higher concentrations of $\mathrm{Cu}$ were found when the slope gradient was between 30.00 to $40.00^{\circ}$, the elevation was less than $600.00 \mathrm{~m}$, and on the south aspects of slopes (slope aspect range from 135.00 to $225.00^{\circ}$ ), while the highest concentrations of $\mathrm{Cr}, \mathrm{Ni}, \mathrm{Zn}$ and $\mathrm{Pb}$ were generally found when the slope gradient was greater than $40.00^{\circ}$, the elevation was between 600.00 and $700.00 \mathrm{~m}$, and on the north aspects of slopes (slope aspect range from 0 to 45.00 and from 315.00 to $360.00^{\circ}$ ).

The spatial distribution in topsoil and subsoil was similar for each individual heavy metal (Fig. 4). Additionally, $\mathrm{Cr}, \mathrm{Ni}, \mathrm{Zn}$ and $\mathrm{Pb}$ showed similar spatial distributions: high metal concentrations were observed at low elevations (foot and toe slopes) and on the south side of the catchment. The slope gradient of the south side of the catchment is less than that of the north side, and the low elevation areas of the catchment (foot and toe slopes and the mouth of the catchment) are characterized by sediment deposition. The spatial distribution pattern of $\mathrm{Cu}$ was contrary to that of $\mathrm{Cr}, \mathrm{Ni}, \mathrm{Zn}$ and $\mathrm{Pb}$, and high $\mathrm{Cu}$ values were mainly found on the north side of the catchment, which is characterized by an extremely high slope gradient.
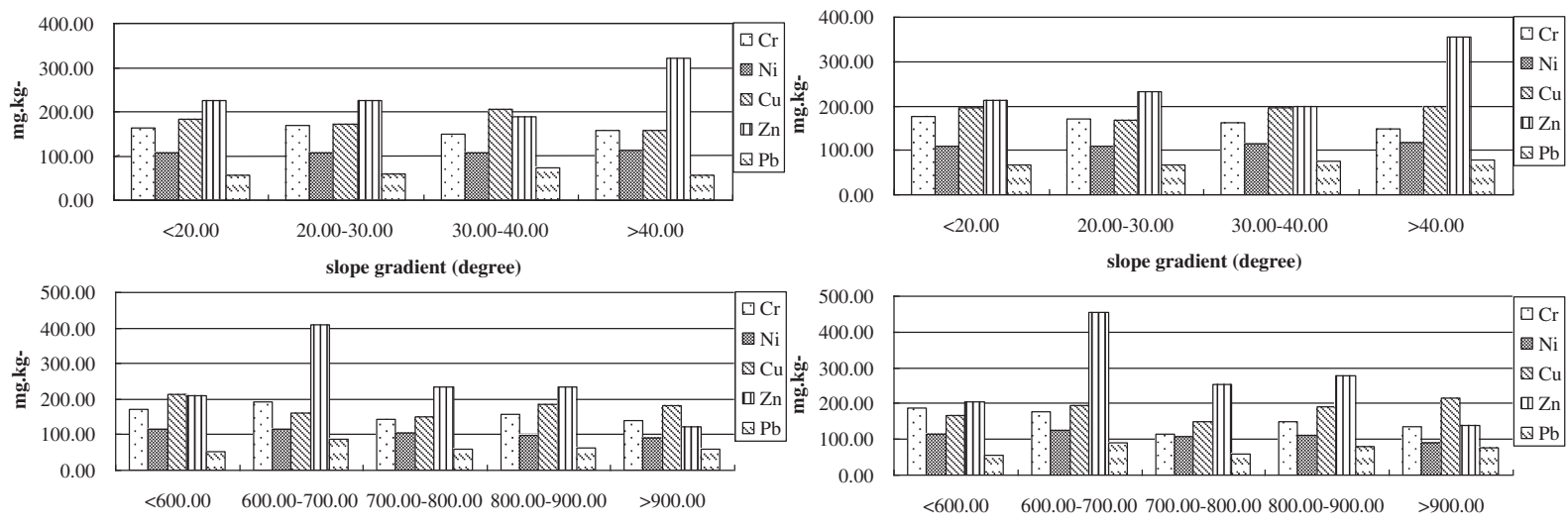

elevation $(\mathbf{m})$
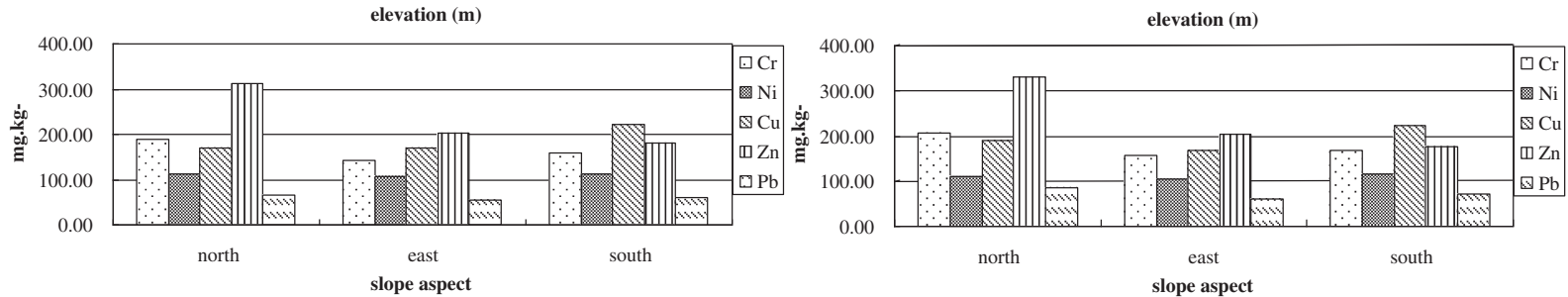

Fig. 3. Heavy metal concentrations (median values) under different slope gradients, elevations and slope aspects in both topsoil (the left column) and subsoil (the right column), 

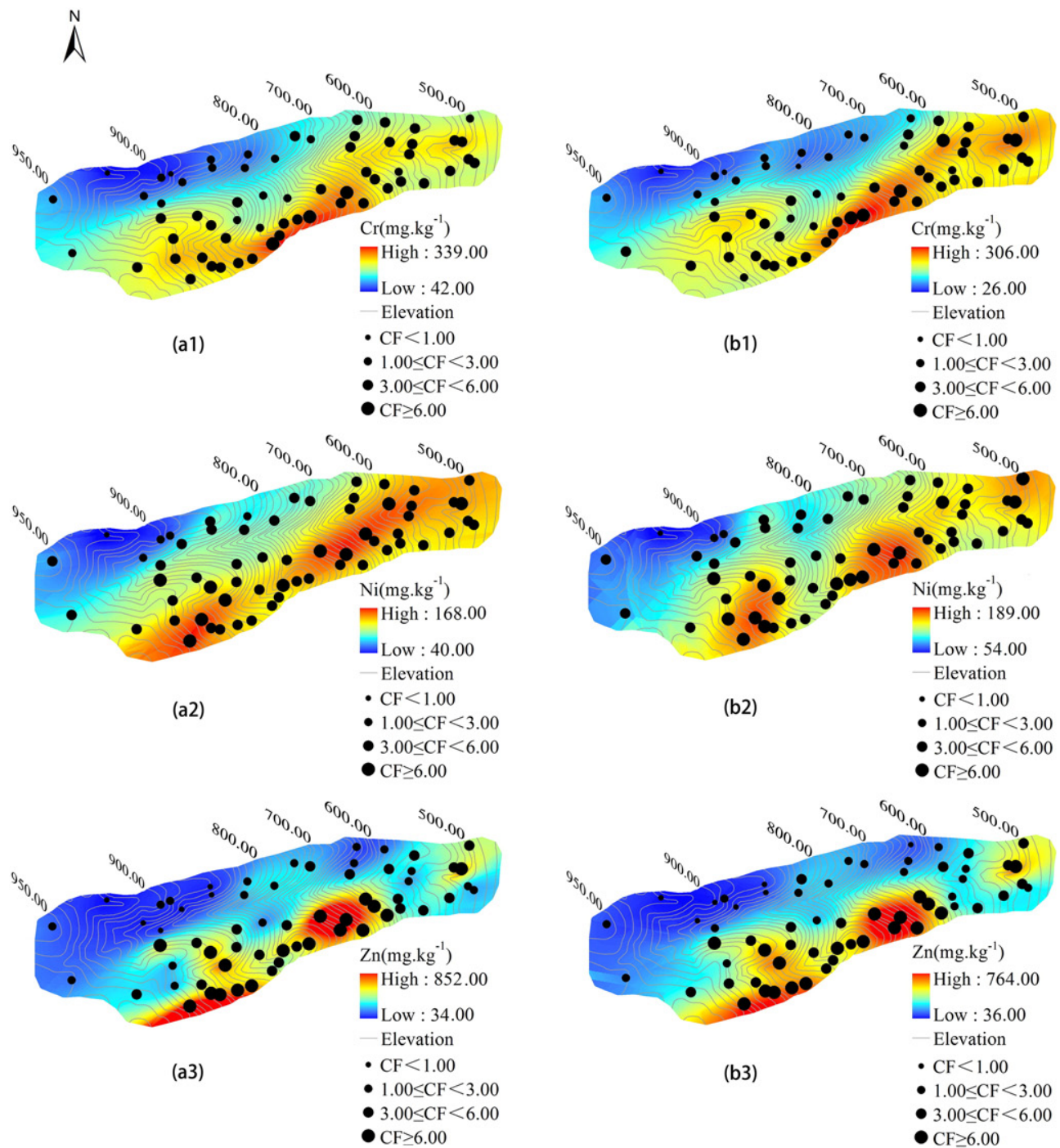

(b3)

$$
\text { - } \mathrm{CF}<1.00
$$

$\leq \mathrm{CF}<6.00$
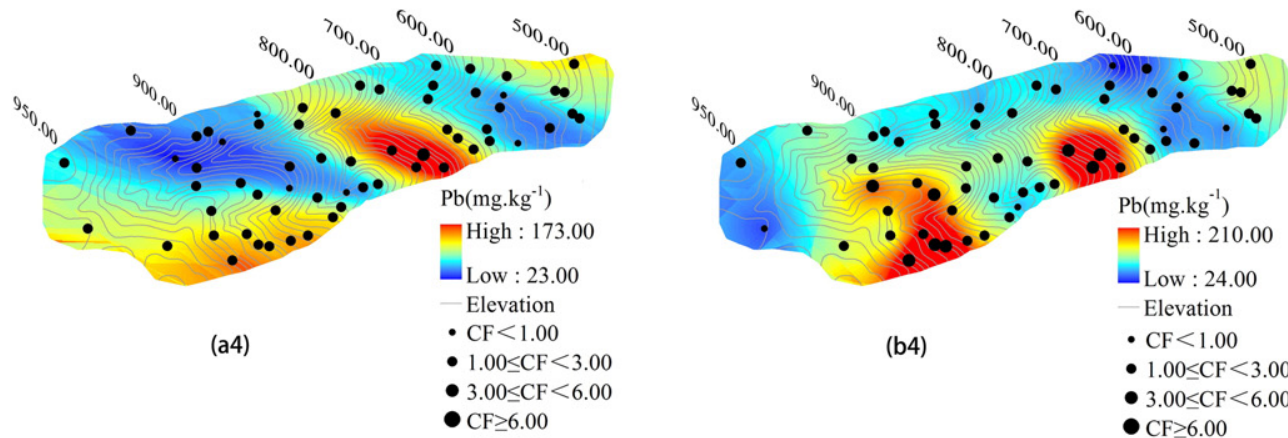

(b4)

Low : 24.00

- Elevation

- $1.00 \leq \mathrm{CF}<3.00$

- $3.00 \leq \mathrm{CF}<6.00$

- $\mathrm{CF} \geq 6.00$
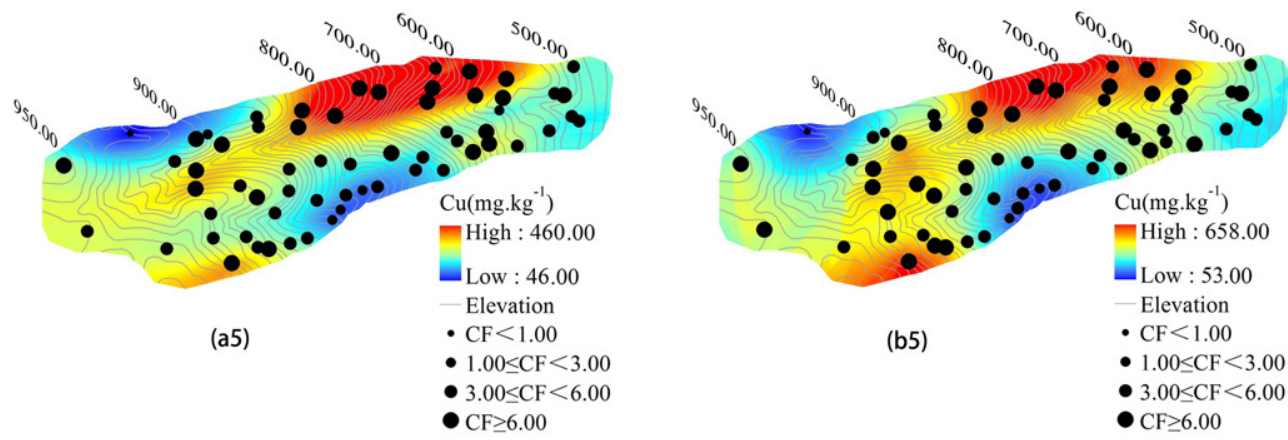

(b5)

Elevation

- $\mathrm{CF}<1.00$

- $1.00 \leq \mathrm{CF}<3.00$

- $3.00 \leq \mathrm{CF}<6.00$

- $\mathrm{CF} \geq 6.00$

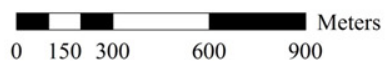

Fig. 4. Spatial distribution of heavy metals in the Laozhai Watershed within the Yunjiang dry-hot Valley. 


\subsection{Relationships between environmental factors and heavy metals}

The concentrations of $\mathrm{Cr}, \mathrm{Ni}, \mathrm{Zn}$, and $\mathrm{Pb}$ were significantly positively correlated with each other in both topsoil and subsoil, while no significant correlations existed between $\mathrm{Cu}$ and the other heavy metals (Table 4). Cr was not correlated with soil properties or topographic factors in topsoil, but in the subsoil layers, $\mathrm{Cr}$ was significantly positively correlated with BD and negatively correlated with El. A significant positive correlation was found between $\mathrm{Ni}$ and $\mathrm{OM}$ and a significant negative correlation was found between $\mathrm{Ni}$ and $\mathrm{El}$ in both topsoil and subsoil, while no correlations were found between $\mathrm{Ni}$ and other soil properties or topographic factors. A significant negative correlation was found between $\mathrm{Cu}$ and $\mathrm{BD}$, and a significant positive correlation was found between $\mathrm{Cu}$ and $\mathrm{Sa}$ in topsoil. However, no correlations were found between $\mathrm{Cu}$ and soil properties or topographic factors in the subsoil. $\mathrm{Zn}$ was significantly negatively correlated with BD in topsoil and was significantly positively correlated with $\mathrm{OM}$ in both topsoil and subsoil. $\mathrm{Pb}$ was significantly positively correlated with OM in topsoil, while no significant correlations were found between $\mathrm{Pb}$ and environmental factors in subsoil (Table 4).

The ordination diagram (Fig. 5, Table 5) was based on CCA of the soil heavy metal data $(\mathrm{Cr}, \mathrm{Ni}, \mathrm{Cu}, \mathrm{Zn}$ and $\mathrm{Pb}$ ) of the 62 monitoring sites, as well as the data of ten environmental variables. In the topsoil, the eigenvalue of the first axis was 0.02 , and that of the second axis was 0.01 . The heavy metal-environmental factor correlations were high for both the first and second axes at 0.50 and 0.46 , respectively. The cumulative percentage of variance of the soil heavy metals explained by the first and second axes was 16.60 , and that for heavy metal-environmental factor relationships was 87.10 . The results indicate that there were strong relationships between heavy metals and environmental factors at the first two axes. Furthermore, compared with topsoil, stronger relationships between heavy metals and environmental factors at the first two axes were found in the subsoil. The eigenvalues for the first and second axes were 0.02 and 0.02 , and the heavy metal-environmental factor correlations were 0.61 and 0.47 , respectively. The cumulative percentage of variance of the soil heavy metals explained by the first and second axes was 22.50 , and for heavy metal-environmental factor relationships, the value was 85.80 .

In the topsoil, $\mathrm{Cu}$ and $\mathrm{Zn}$ were closely correlated with the first axis, and $\mathrm{Pb}, \mathrm{Cr}$ and $\mathrm{Ni}$ were correlated with the second axis (Fig. 5). The locations of the heavy metals on the graph in relation to the lines representing the environmental variables indicated a positive correlation between the concentrations of $\mathrm{Cr}$ and silt; furthermore, $\mathrm{Cr}$ was negatively correlated with As, and the environmental factor with the highest correlation was silt. Ni was positively correlated with clay and $\mathrm{pH}$ and was negatively correlated with El and Sand; the environmental factor showing the highest correlation was $\mathrm{pH}$. Cu was positively correlated with As and was negatively correlated with $\mathrm{BD}$; the environmental factor with the highest correlation was As. Zn was negatively correlated with SWI. Pb was positively correlated with OM and sand and was negatively correlated with clay; the environmental factor showing the highest correlation was OM.

In the subsoil, $\mathrm{Pb}, \mathrm{Cr}$ and $\mathrm{Ni}$ were closely correlated with the first axis, and $\mathrm{Cu}$ and $\mathrm{Zn}$ were correlated with the second axis (Fig. 5). The ordination diagram shows a positive correlation between the concentration of $\mathrm{Cr}$ and $\mathrm{pH}$. Furthermore, $\mathrm{Cr}$ was negatively correlated with As, and the environmental factor with the highest correlation was silt. $\mathrm{Ni}$ was positively correlated with $\mathrm{pH}$ and was negatively correlated with Sl; the environmental factor showing the highest correlation was $\mathrm{pH}$. Cu was positively correlated with sand and was negatively correlated with BD and clay; the environmental factor with the highest correlation was sand. Zn was positively correlated with OM and negatively correlated with SWI; the environmental factor showing the highest correlation was $\mathrm{OM}$. $\mathrm{Pb}$ was positively correlated with $\mathrm{Sl}$ and was

Table 4

Correlation coefficients among environmental factors and heavy metals $(n=62)$.

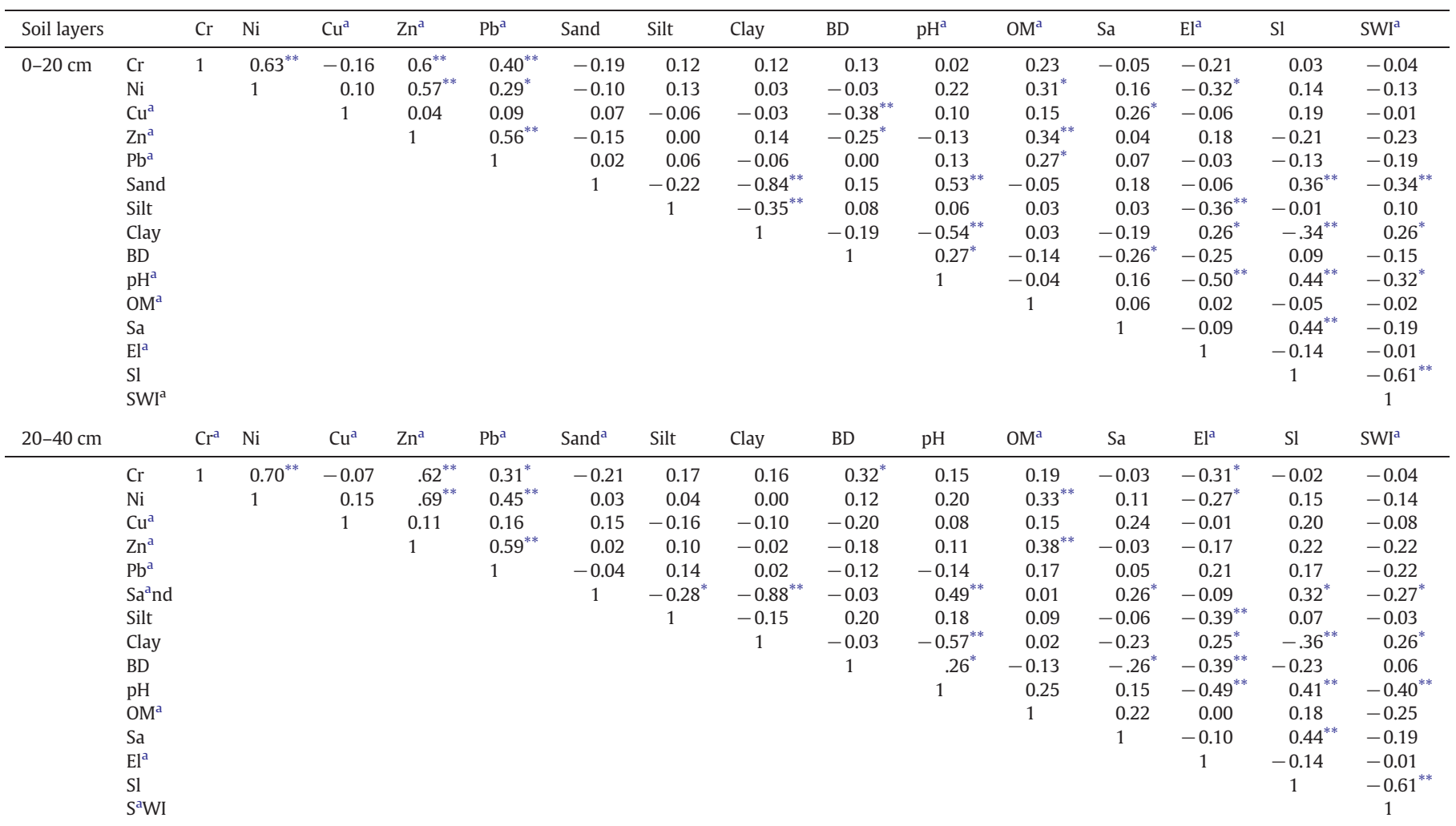

${ }^{\mathrm{a}}$ Box-Cox transformation.
${ }^{*} \mathrm{p}<0.05$.

** $\mathrm{p}<0.01$. 

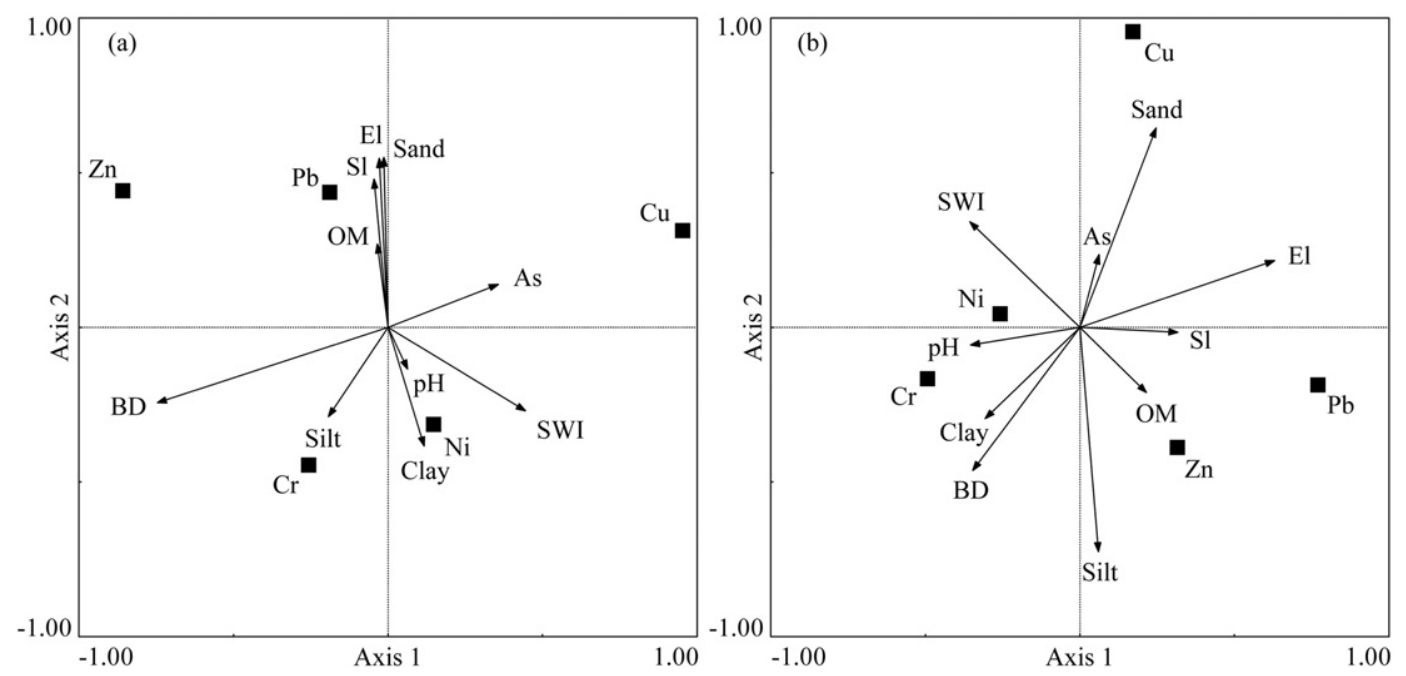

Fig. 5. Ordination plots of the canonical correspondence analysis (CCA) for the metal concentrations and different environmental factors in topsoil (a) and subsoil (b).

negatively correlated with $\mathrm{pH}$; the environmental factor showing the highest correlation was Sl (Fig. 5).

In conclusion, the concentrations of heavy metals in the topsoil were controlled by both soil and topographical factors, while in the subsoil, they were mainly controlled by soil-related factors. Specifically, the concentrations of $\mathrm{Cr}$ and $\mathrm{Ni}$ in both topsoil and subsoil were mainly controlled by the soil-related factors of silt and $\mathrm{pH}$, respectively. The concentration of $\mathrm{Pb}$ was controlled by $\mathrm{OM}$ in the topsoil and by $\mathrm{Sl}$ in the subsoil. The concentrations of $\mathrm{Cu}$ and $\mathrm{Pb}$ were mainly determined by the topographical factors of As and SWI, respectively, in topsoil and by the soil-related factors of sand and OM, respectively, in the subsoil.

\section{Discussion}

\subsection{Heavy metal contamination in the DHV}

We compared the concentrations of heavy metals observed in our study with those reported for other areas in China and elsewhere (Table 6). Notably, the concentrations of heavy metals found in our study were higher than those reported in most other areas, except for Ni concentration, which was higher in Serbia (Dragović et al., 2008). The mean concentration of $\mathrm{Pb}$ in our study was similar to that observed in Beijing (Lu et al., 2012) and Guangzhou (Li et al., 2009) and lower than that reported for Izmit Bay (Pekey, 2006).

High concentrations of heavy metals in the DHV may be attributed to this area's distinctive physical geography and to farming systems. First, under the unique hot and dry soil-forming environment, the background concentrations of heavy metals in the torrid red soil are higher than those found in other soil types. Additionally, the background levels of $\mathrm{Cu}$ and $\mathrm{Pb}$ for torrid red soil were the highest of the 41 types of soils tested according to the results of the National Survey (Ministry of Environmental Protection of the People's Republic of China, 1990). For example, a very high $\mathrm{Cr}$ concentration of $762.90 \mathrm{mg} \cdot \mathrm{kg}^{-1}$ was observed in the river bed sands in the Mekong River, and torrid red soil is widely distributed in that region's DHV (Fu et al., 2012). Furthermore, a combination of factors (low precipitation and high evaporation; Zhang, 1992), steep slopes (Table 1), and loss of farm labor in recent years (Xia, 2009) limited the implementation of alternative farming practices in the DHV region. Consequently, farmers intended to use large quantities of fertilizer (both chemical and manure) and pesticides instead of irrigation, cultivation, and weeding. These practices resulted in the accumulation of $\mathrm{Sr}, \mathrm{Ni}, \mathrm{Cu}, \mathrm{Zn}$, and $\mathrm{Pb}$ in the soils used for agriculture (Wuana and Okieimen). Additionally, the DHV in the Upper Red River is well known for its rich mineral resources (Zhao, 1992). A large copper deposit called Dahongshan is situated in the Yunjiang DHV (Qin et al., 2000) approximately $20 \mathrm{~km}$ away from our study area. The coppermining, iron, and steel industries may accelerate heavy metal contamination in soils (Rey et al., 2013; Sun et al., 2010).

Soil erosion in the DHV is severe because of the high sand content in soils and the steep slopes in this region, and it may increase sediment yield in the Red River (Yang et al., 2002). The erosion modulus was as high as $12,000.00 \mathrm{t} \cdot \mathrm{km}^{-2} \cdot \mathrm{a}^{-1}$ in a similar typical DHV (Chai, 1995), where the soil loss tolerance is only $500.00 \mathrm{t} \cdot \mathrm{km}^{-2} \cdot \mathrm{a}^{-1}$ (Ministry of Environmental Protection of the People's Republic of China, 1990). Moreover, a Chinese proposal to develop hydropower capacity by constructing twelve large-scale dams in the Upper Red River (Zhai et al., 2007) may result in the submersion of parts of the DHV. Consequently, high concentrations of heavy metals, severe soil erosion, and the new dam construction may interact to make the DHV a potential source of heavy metal pollution in the Red River. Local governments need to consider this issue when plans for the dam construction as a "cascade reservoir system" are implemented. Specifically, effective soil remediation and soil and water conservation measures will be needed in the DHV to prevent heavy metal contamination in the Red River.

Table 5

Eigenvalues and cumulative percentages of CCA analysis.

\begin{tabular}{|c|c|c|c|c|c|c|c|c|}
\hline \multirow{2}{*}{$\frac{\text { Soil layers }}{\text { Ordination axes }}$} & \multicolumn{4}{|c|}{ Top soil } & \multicolumn{4}{|c|}{ Sub soil } \\
\hline & AX1 & AX2 & AX3 & AX4 & AX1 & AX2 & AX3 & AX4 \\
\hline Eigenvalues & 0.02 & 0.01 & 0.00 & 0.00 & 0.02 & 0.02 & 0.01 & 0.00 \\
\hline Coefficient of heavy metals-environment correlation & 0.50 & 0.46 & 0.33 & 0.20 & 0.61 & 0.47 & 0.48 & 0.31 \\
\hline Cumulative percentage of heavy metals date explained by ordination axes & 11.10 & 16.60 & 18.70 & 19.10 & 12.40 & 22.50 & 25.50 & 26.30 \\
\hline $\begin{array}{l}\text { Cumulative percentage of heavy metals-environment correlation explained } \\
\text { by ordination axes }\end{array}$ & 57.90 & 87.10 & 97.80 & 100.00 & 47.10 & 85.50 & 97.00 & 100.00 \\
\hline
\end{tabular}


Table 6

Comparison of heavy metal concentrations $\left(\mathrm{mg} \cdot \mathrm{kg}^{-1}\right)$ in agricultural soils worldwide.

\begin{tabular}{|c|c|c|c|c|c|c|}
\hline \multirow[t]{2}{*}{ Sources } & \multirow[t]{2}{*}{ District (Country) } & \multicolumn{5}{|c|}{ Concentrations of heavy metals } \\
\hline & & $\mathrm{Cr}$ & $\mathrm{Ni}$ & $\mathrm{Cu}$ & $\mathrm{Zn}$ & $\mathrm{Pb}$ \\
\hline Micó et al. (2006) & Mediterranean area & $26.50 \pm 5.90$ & $20.90 \pm 5.10$ & $22.50 \pm 8.90$ & $52.80 \pm 12.90$ & $22.80 \pm 16.10$ \\
\hline Kelepertzis (2014) & Peloponnese, Greece & $83.12 \pm 48.25$ & $146.80 \pm 120.30$ & $74.68 \pm 63.87$ & $74.88 \pm 32.80$ & $19.74 \pm 7.44$ \\
\hline Manz et al. (1999) & Bitterfeld, Germany & 52.40 & 20.90 & - & 75.00 & 40.00 \\
\hline Facchinelli et al. (2001) & Piemonte, Italy & 46.20 & 83.20 & - & 62.70 & 16.10 \\
\hline Ahmad and Goni (2010) & Dhaka, Bangladesh & 53.70 & 58.20 & - & 115.00 & 49.70 \\
\hline Romic and Romic (2003) & Zagreb, Croatia & - & 49.50 & 20.80 & 77.90 & 25.90 \\
\hline Pekey (2006) & Izmit Bay, Turkey & $153.00 \pm 3.40$ & $32.07 \pm 2.80$ & $70.70 \pm 2.10$ & $123.50 \pm 4.50$ & $450.00 \pm 6.60$ \\
\hline Dragović et al. (2008) & Zlatibor, Serbia & 46.30 & 320.00 & 8.64 & 21.80 & 41.50 \\
\hline Hani and Pazira (2011) & Tehran, Iran & $67.96 \pm 32.82$ & $36.92 \pm 14.08$ & $36.09 \pm 22.72$ & $217.99 \pm 119.44$ & $16.46 \pm 8.63$ \\
\hline Lu et al. (2012) & Beijing, China & - & - & $22.40 \pm 6.31$ & $20.40 \pm 5.20$ & $69.80 \pm 16.50$ \\
\hline Cai et al. (2012) & Huizhou, China & 27.61 & 14.89 & 16.74 & 57.21 & 44.66 \\
\hline Zhou et al. (2014) & Huanghuai Plain, China & $79.00 \pm 30.00$ & $35.30 \pm 25.90$ & - & $73.80 \pm 46.30$ & $25.3 \pm 5.38$ \\
\hline Lee et al. (2006) & Hong Kong, China & 21.80 & 5.3 & - & 46.80 & 39.60 \\
\hline Yang et al. (2009) & Taihang Plain, China & 52.80 & 25.00 & - & 69.90 & 18.80 \\
\hline Huang et al. (2007) & Yangzhong, China & 77.20 & 38.50 & - & 98.10 & 35.70 \\
\hline Li et al. (2009) & Guangzhou, China & - & - & $38.80 \pm 48.70$ & $158.60 \pm 82.20$ & $69.40 \pm 37.40$ \\
\hline Wong et al. (2002) & Pearl River Delta, China & 71.40 & 21.20 & 33.00 & 84.70 & 40.00 \\
\hline This study & Dry-hot valley, China & $166.16 \pm 61.15$ & $108.61 \pm 26.20$ & $193.37 \pm 83.32$ & $266.89 \pm 182.98$ & $69.98 \pm 26.84$ \\
\hline
\end{tabular}

\subsection{Spatial distribution and environmental controls of soil heavy metals in the DHV}

Correlations among different heavy metals can be used to explain their spatial distributions and sources in soils (Navas and Machín, 2002; Zhou et al., 2014). The correlations among different soil heavy metals (Table 4) indicate a common source of $\mathrm{Cr}, \mathrm{Ni}, \mathrm{Zn}$, and $\mathrm{Pb}$ and a separate source of $\mathrm{Cu}$ in the Laozhai watershed. Heavy metals in agricultural soils originate from either an anthropogenic or a geogenic/ pedogenic source (Dragović et al., 2008; Raymond and Okieimen, 2001). $\mathrm{Zn}, \mathrm{Ni}, \mathrm{Cr}$, and $\mathrm{Pb}$ are widely attributed to anthropogenic sources (Kelepertzis, 2014; Qi et al., 2010; Raymond and Okieimen, 2001). The content of $\mathrm{Pb}$ in agricultural soils may increase after the use of phosphatic fertilizers. Additionally, the application of pesticides, biosolids, or manures may lead to the accumulation of $\mathrm{Zn}, \mathrm{Ni}, \mathrm{Cr}$, and $\mathrm{Pb}$ (Alloway, 2013; Raymond and Okieimen, 2001). Corn and sugar cane are widely planted in the Laozhai catchment, and chemical fertilizers, pesticides, and pig manures are used annually to increase crop production. These agricultural practices could be a major reason for the accumulation of $\mathrm{Zn}, \mathrm{Ni}, \mathrm{Cr}$, and $\mathrm{Pb}$ in the study area. The application of chemical fertilizers, pesticides, and manures may also increase $\mathrm{Cu}$ content in agricultural soils (Dragović et al., 2008; Raymond and Okieimen, 2001). However, in this study, there was a strong relationship between $\mathrm{Cu}$ and the soil physical properties of $\mathrm{BD}$ and sand and silt contents (Table 4), and the spatial distribution of Cu was different than that of $\mathrm{Cr}, \mathrm{Ni}, \mathrm{Zn}$ and $\mathrm{Pb}$, indicating a different source of $\mathrm{Cu}$. The Dahongshan mine is a large $\mathrm{Cu}$ mine that is situated $20 \mathrm{~km}$ away from the Laozhai catchment (Qin et al., 2000), and the accumulation of $\mathrm{Cu}$ in soils may be attributed primarily to the bedrock influence in the study area. Furthermore, low elevations and the south side of the Laozhai catchment are used mainly for farming (Fig. 1). Because of the relatively low slope gradients and easy access, farmers tend to use more chemical fertilizers, manures, and pesticides here compared with other locations. These practices are likely to result in high concentrations of $\mathrm{Cr}, \mathrm{Ni}, \mathrm{Zn}$, and $\mathrm{Pb}$.

CCA analysis has been widely used to identify the environmental controls of heavy metals (Beasley and Kneale, 2003; Read et al., 1998). Soil properties and topographic factors may play an important role in the mobility and bioavailability of heavy metals, thus influencing their distribution in soils (Agarwal et al., 2005; Fu et al., 2014). Topographical factors may impact sediment transport (He et al., 2004; Quinton and Catt, 2007), and we conclude that these factors may be the reason for the high concentrations of $\mathrm{Cr}, \mathrm{Ni}, \mathrm{Zn}$ and $\mathrm{Pb}$ found on the south-facing slopes and at low elevations in our study area. This is because gentle slopes are conducive to sediment deposition (Aksoy and Kavvas, 2005; Fang et al., 2013). In the topsoil, the parent materials, sediment transport and agricultural management strategies influence the concentrations of heavy metals. However, in the subsoil, the concentrations of heavy metals may mainly be influenced by the parent materials. As a result, in topsoil, the concentrations of heavy metals were controlled by both soil-related and topographical factors, whereas they were mainly controlled by soil-related factors in the subsoil.

\section{Conclusions}

The objectives of this study were to outline the accumulation of and environmental controls over heavy metals in the DHV of the Upper Red River. Our results indicated that the average concentrations of $\mathrm{Cr}, \mathrm{Ni}, \mathrm{Cu}$, $\mathrm{Zn}$, and $\mathrm{Pb}$ in the DHV region exceeded their background levels and were higher than most of those reported in agricultural soils worldwide. $\mathrm{Cu}$ had the highest contamination factor, followed by $\mathrm{Ni}, \mathrm{Zn}, \mathrm{Cr}$, and $\mathrm{Pb}$, in that order. High levels of heavy metal contamination may have resulted from the uncontrolled application of fertilizers and pesticides, as well as from mining in the DHV region. The spatial distribution of heavy metals in topsoil and subsoil was similar for each individual heavy metal. $\mathrm{Cr}$, Ni, $\mathrm{Zn}$ and $\mathrm{Pb}$ exhibited similar spatial distribution patterns; high concentrations of these metals were observed at low elevations or on the south side of the catchment and in areas with relatively low slope gradients and frequent farming activities. The spatial distribution of $\mathrm{Cu}$ was distinct from those of $\mathrm{Cr}, \mathrm{Ni}$, and $\mathrm{Zn}$. The heavy metal contents of $\mathrm{Cr}, \mathrm{Ni}, \mathrm{Zn}$, and $\mathrm{Pb}$ were significantly positively correlated in both topsoil and subsoil, while Cu was not correlated with the other heavy metals. The concentrations of $\mathrm{Cr}$ and $\mathrm{Ni}$ in both topsoil and subsoil were mainly controlled by the soil-related factors of silt and $\mathrm{pH}$, respectively. The concentration of $\mathrm{Pb}$ was controlled by $\mathrm{OM}$ in the topsoil and by $\mathrm{Sl}$ in the subsoil. The concentrations of $\mathrm{Cu}$ and $\mathrm{Pb}$ were mainly determined by the topographical factors of As and SWI, respectively, in topsoil and by the soil-related factors of sand and OM in subsoil. Chemical fertilizers, pesticides, and pig manures could be the major reason for the accumulation of $\mathrm{Zn}, \mathrm{Ni}, \mathrm{Cr}$, and $\mathrm{Pb}$ in the study area, while the accumulation of $\mathrm{Cu}$ may be attributed primarily to mining and bedrock influences. High concentration of heavy metals, severe soil erosion, and the proposed plan to dam the river system may interact to make the DHV a potential source of heavy metal pollution for the Red River. Local governments must consider this issue when construction of the "cascade reservoir system" is implemented. Effective soil remediation measures and soil and water conservation are needed in the DHV to prevent heavy metal contamination in the Red River. 


\section{Acknowledgments}

This work has been supported by the National Natural Science Foundation of China (Grant numbers: 41101267 and 41301099), the National Science and Technology Support Program (2013BAB06B03), and the Department of Water Resources of Yunnan Province: Water Science and Technology Project.

\section{References}

Agarwal, A., Singh, R.D., Mishra, S.K., Bhunya, P.K., 2005. ANN-based sediment yield river basin models for Vamsadhara (India). Water SA 31, 95-100.

Ahmad, J.U., Goni, M.A., 2010. Heavy metal contamination in water, soil, and vegetables of the industrial areas in Dhaka, Bangladesh. Environ. Monit. Assess. 66, 347-357.

Aksoy, H., Kavvas, M.L., 2005. A review of hillslope and watershed scale erosion and sediment transport models. Catena 64 (2-3), 247-271.

Alloway, B.J., 2013. Heavy Metals in Soils: Trace Metals and Tetalloids in Soils and Their Bioavailability. 3rd ed. Springer Dordrecht Heidelberg, New York London.

Beasley, G., Kneale, P.E., 2003. Investigating the influence of heavy metals on macroinvertebrate assemblages using partial cononical correspondence analysis (pCCA). Hydrol. Earth Syst. Sci. Discuss. 7 (2), 221-233.

Cai, L.M., Xu, Z.C., Ren, M.Z., Guo, Q.W., Hu, X.B., Hu, G.C., Wan, H.F., Peng, P.G., 2012. Source identification of eight hazardous heavy metals in agricultural soils of Huizhou, Guangdong Province, China. Ecotoxicol. Environ. Saf. 78, 2-8.

Cenci, R.M., Martin, J.M., 2004. Concentration and fate of trace metals in Mekong River Delta. Sci. Total Environ. 332 (1), 167-182.

Chai, Z.X., 1995. Regionalization of soil and water loss in southwest China. Mt. Res. 13 (2), 121-127 (in Chinese).

Cressie, N., 1988. Spatial prediction and ordinary kriging. Math. Geol. 20 (4), 405-421.

Dragović, S., Mihailović, N., Gajić, B., 2008. Heavy metals in soils: distribution, relationship with soil characteristics and radionuclides and multivariate assessment of contamination sources. Chemosphere 72 (3), 491-495.

Facchinelli, A., Sacchi, E., Mallen, L., 2001. Multivariate statistical and GIS-based approach to identify heavy metal sources in soils. Environ. Pollut. 114 (3), 313-324.

Fang, H.Y., Sheng, M.L., Tang, Z.H., Cai, Q.G., 2013. Assessment of soil redistribution and spatial pattern for a small catchment in the black soil region, Northeastern China: using fallout 210Pbex. Soil Tillage Res. 133, 85-92.

Fu, K.D., Su, B., He, D.M., Lu, X.X., Song, J.Y., Huang, J.C., 2012. Pollution assessment of heavy metals along the Mekong River and dam effects. J. Geogr. Sci. 22 (5), 874-884.

Fu, J., Zhao, C.P., Luo, Y.P., Liu, C.S., Luo, Y., Zhao, D.Y., An, S.Q., Zhu, H.L., 2014. Heavy metals in surface sediments of the Jialu River, China: their relations to environmental factors. J. Hazard. Mater. 270, 102-109.

Fujita, M., Ide, Y., Sato, D., 2014. Heavy metal contamination of coastal lagoon sediments: Fongafale Islet, Funafuti Atoll, Tuvalu. Chemosphere 95, 628-634.

Hakanson, L., 1980. An ecological risk index for aquatic pollution control. A sedimentological approach. Water Res. 14 (8), 975-1001.

Hani, A., Pazira, E., 2011. Heavy metals assessment and identification of their sources in agricultural soils of Southern Tehran, Iran. Environ. Monit. Assess. 176 (1-4), 677-691.

He, Z.L., Zhang, M.K., Calvert, D.V., Stoffella, P.J., Yang, X.E., Yu, S., 2004. Transport of heavy metals in surface runoff from vegetable and citrus fields. Soil Sci. Soc. Am. J. 68, 1662-1669.

He, Z.L., Yang, X.E., Stoffella, P.J., 2005. Trace elements in agroecosystems and impacts on the environment. J. Trace Elem. Med. Biol. 19 (2-3), 125-140.

He, D.M., Ren, J., Fu, K.D., Li, Y.G., 2007. Sediment change under climate changes and human activities in the Yuanjiang-Red River Basin. Chin. Sci. Bull. 52 (2), 164-171.

Heredia, O.S., Cirelli, A.F., 2009. Trace elements distribution in soil, pore water and groundwater in Buenos Aires, Argentina. Geoderma 149 (3), 409-414.

Huang, S.S., Liao, Q.L., Hua, M., Wu, X.M., Bi, K.S., Yan, C.Y., Chen, B., Zhang, X.Y., 2007. Survey of heavy metal pollution and assessment of agricultural soil in Yangzhong district, Jiangsu Province, China. Chemosphere 67, 2148-2155.

Ji, Z.H., Fang, H.D., Yang, Y.X., Pan, Z.X., Sha, Y.C., 2009. Assessment of system functions after vegetation restoration of the degraded ecosystem in arid-hot valleys of Jinsha River: a case study on small watershed of Yuanmou. Ecol. Environ. Sci. 18 (4), 1383-1389 (in Chinese).

Kelepertzis, E., 2014. Accumulation of heavy metals in agricultural soils of Mediterranean: insights from Argolida basin, Peloponnese, Greece. Geoderma 221, 82-90.

Kitov, B.I., 2000. Calculation features of the fundamental parameter method in XRF. X-Ray Spectrom. 29, 285-290.

Le, T.P.Q., Garnier, J., Gilles, B., Sylvain, T., Minh, V.C., 2007. The changing flow regime and sediment load of the Red River, Viet Nam. J. Hydrol. 334, 199-214.

Lee, C.S., Li, X., Shi, W., Cheung, S.C., Thornton, I., 2006. Metal contamination in urban, suburban, and country park soils of Hong Kong: a study based on GIS and multivariate statistics. Sci. Total Environ. 356, 45-61.

Lepš, J., Šmilauer, P., 2003. Multivariate Analysis of Ecological Data Using CANOCO. Cambridge University Press, York

Li, J.H., Lu, Y., Yin, W., Gan, H.H., Zhang, C., Deng, X.L., Lian, J., 2009. Distribution of heavy metals in agricultural soils near a petrochemical complex in Guangzhou, China. Environ. Monit. Assess. 153, 365-375.

Li, Z.G., Feng, X.B., Li, G.H., Bi, X.Y., Zhu, J.M., Qin, H.B., Dai, Z.H., Liu, J.L., Li, Q.H., Sun, G.Y., 2013. Distributions, sources and pollution status of 17 trace metal/metalloids in the street dust of a heavily industrialized city of central China. Environ. Pollut. 182, 408-416.
Liu, G.S., 1996. Soil Physics and Chemistry Analysis and Description of Soil Profiles. China Standard Press, Beijing (in Chinese).

Lu, A., Wang, J., Qin, X., Wang, K., Han, P., Zhang, S., 2012. Multivariate and geostatistical analyses of the spatial distribution and origin of heavy metals in the agricultural soils in Shunyi, Beijing, China. Sci. Total Environ. 425, 66-74.

Manz, M., Weissflog, L., Kühne, R., Schüürmann, G., 1999. Ecotoxicological hazard and risk assessment of heavy metal contents in agricultural soils of Central Germany. Ecotoxicol. Environ. Saf. 42, 191-201.

Martín, J.A.R., Arias, M.L., Corbi, J.M.G., 2006. Heavy metals contents in agricultural topsoils in the Ebro basin (Spain). Application of the multivariate geoestatistical methods to study spatial variations. Environ. Pollut. 144 (3), 1001-1012.

Miao, C.Y., Ni, J.R., Borthwick, A.G.L., 2010. Recent changes in water discharge and sediment load of the Yellow River basin, China. Prog. Phys. Geogr. 34 (4), 541-561.

Micó, C., Recatalá, L., Peris, M., Sánchez, J., 2006. Assessing heavy metal sources in agricultural soils of an European Mediterranean area by multivariate analysis. Chemosphere 65 (5), 863-872.

Ministry of Environmental Protection of the People's Republic of China, 1990. Background Concentration of Soil Elements in China. China Environmental Science Press, Beijing (in Chinese).

Morgan, R.P.C., 2009. Soil Erosion and Conservation. John Wiley \& Sons.

National Soil Survey Office, 1998. Soils of China. China Agriculture Press, Beijing, pp. 274-275 (in Chinese).

Navas, A., Machín, J., 2002. Spatial distribution of heavy metals and arsenic in soils of Aragón (northeast Spain): controlling factors and environmental implications. Appl. Geochem. 17, 961-973.

Pan, K., Wang, W.X., 2012. Trace metal contamination in estuarine and coastal environments in China. Sci. Total Environ. 421, 3-16.

Pei, T., Qin, C.Z., Zhu, A., Yang, L., Luo, M., Li, B.L., Zhou, C.H., 2010. Mapping soil organic matter using the topographic wetness index: a comparative study based on different flow-direction algorithms and kriging methods. Ecol. Indic. 10 (3), 610-619.

Pekey, H., 2006. The distribution and sources of heavy metals in Izmit Bay surface sediments affected by a polluted stream. Mar. Pollut. Bull. 52, 1-12.

Phan, K., Phan, S., Huoy, L., Suy, B., Wong, M.H., Hashim, J.H., Aljunid, S.M., Sthiannopkao S., Kim, K.W., 2013. Assessing mixed trace elements in groundwater and their health risk of residents living in the Mekong River basin of Cambodia. Environ. Pollut. 182 111-119.

Qi, S., Leipe, T., Rueckert, P., Zhou, D., Harff, J., 2010. Geochemical sources, deposition and enrichment of heavy metals in short sediment cores from the Pearl River Estuary, Southern China. J. Mar. Syst. 82, S28-S42.

Qin, D.X., Yan, Y.F., Tian, Y.L., Liu, W., 2000. Geological characteristics and ore-forming evolution of Dahongshan copper deposit. Sci. Geol. Sin. 35 (2), 129-139 (in Chinese)

Quinton, J.N., Catt, J.A., 2007. Enrichment of heavy metals in sediment resulting from soil erosion on agricultural fields. Environ. Sci. Technol. 41 (10), 3495-3500.

Raymond, A.W., Okieimen, F.E., 2001. Heavy Metals in Contaminated Soils: A Review of Sources, Chemistry, Risks and Best Available Strategies for Remediation. International Scholarly Research Network, ISRN Ecology, pp. 1-20.

Read, H.J., Martin, M.H., Rayner, J.M.V., 1998. Invertebrates in woodlands polluted by heavy metals--an evaluation using canonical correspondence analysis. Water Air Soil Pollut. 106 (1-2), 17-42.

Rey, J., Martíne, J., Hidalgo, M.C., Rojas, D., 2013. Heavy metal pollution in the Quaternary Garza basin: a multidisciplinary study of the environmental risks posed by mining (Linares, southern Spain). Catena 110, 234-242.

Romic, M., Romic, D., 2003. Heavy metals distribution in agricultural topsoils in urban area. Environ. Geol. 43, 795-805.

Sakia, R.M., 1992. The Box-Cox transformation technique: a review. Statistician 169-178

Shao, X.X., Huang, B., Zhao, Y.C., Sun, W.X., Gu, Z.Q., Qian, W.F., 2014. Impacts of human activities and sampling strategies on soil heavy metal distribution in a rapidly developing region of China. Ecotoxicol. Environ. Saf. 104, 1-8.

Sherman, J., 1956. The theoretical derivation of fluorescent X-ray intensities from mixtures. Spectrochim. Acta 7, 283-306.

Song, W., Chen, B.M., Liu, L., 2013. Soil heavy metal pollution of cultivated land in China. Res. Soil Water Conserv. 20 (2), 293-298 (In Chinese).

Steininger, K.W., 2003. National environmentally counterproductive support measures in transport: a transboundary pollutant. In: Marsiliani, L., Rausche, M., Withagen, C. (Eds.), Environmental Policy in an International Perspective. Economy \& Environment 26, pp. 265-281

Sumfleth, K., Duttmann, R., 2008. Prediction of soil property distribution in paddy soil landscapes using terrain data and satellite information as indicators. Ecol. Indic. 8 (5), 485-501.

Sun, Y.B., Zhou, Q.X., Xie, X.K., Liu, R., 2010. Spatial, sources and risk assessment of heavy metal contamination of urban soils in typical regions of Shenyang, China. J. Hazard. Mater. 174 (1), 455-462.

Tan, Heping, Gao, Y., Hao, L.V., Zhang, Y.L., Sun, Y.J., 2012. The research of non-standard test method in soil heavy metal by X-ray fluorescence spectrometry. Ecol. Environ. Sci. 21 (4), 760-763 (in Chinese).

The State Council of the People's Republic of China, 2012. National “12th Five-Year Plan” for environmental protection. China Environmental Science Press, Beijing (in Chinese).

Wang, K.Q., Shen, Y.X., Chen, Q.B., Wang, Z.H., 2004. Soil water environment of artificial vegetation in Jinshajiang dry-hot valley. Chin. J. Appl. Ecol. 15 (5), 809-813 (in Chinese).

Wilson, J.P., Gallant, J.C., 2000. Digital terrain analysis, in: Terrain Analysis: Principles and Application. John Wiley and Sons, NewYork, pp. 1-27.

Wong, S.C., Li, X.D., Zhang, G., Qi, S.H., Min, Y.S., 2002. Heavy metals in agricultural soils of the Pearl River Delta, South China. Environ. Pollut. 119, 33-44.

Wuana, R.A., Okieimen, F.E., 2011. Heavy metals in contaminated soils: a review of sources, chemistry, risks and best available strategies for remediation. ISRN Ecol. $1-20$. 
Xia, L.Y., 2009. Negative effects of labor force drain on rural economy. J. Nan Jing Agric. Univ. (Soc. Sci. Ed.) 9 (1), 14-19 (in Chinese).

Yang, W.Q., Wang, K.Y., Song, G.Y., He, Y.R., 2002. Preliminary study on biological characteristics of degraded soil ecosystems in dry hot valley of the Jinsha River. Pedosphere 12 (4), 365-372.

Yang, Z., Xiong, D.H., Zhou, H.Y., Zhang, X.B., 2003. Rainfall infiltration on hilly slopes under various lithology and its effect on tree growth in the dry-hot valley. Sci. China Ser. E: Technol. Sci. 46, 110-119 (in Chinese).

Yang, P.G., Mao, R.Z., Shao, H.B., Gao, Y.F., 2009. The spatial variability of heavy metal distribution in the suburban farmland of Taihang Piedmont Plain. China. C. R. Biol. 332, $558-566$.

Zhai, H.J., Cui, B.S., Hu, B., Wei, G.L., Liu, S.L., 2007. The changing of regional ecosystem under different force of cascade hydropower development situation in the Longitudinal Range-Gorge Region. Chin. Sci. Bull. 52 (Suppl. 2), 93-100 (in Chinese).
Zhang, R.Z., 1992. Dry Valley in Henduan Mountainous Region. Science Press, Beijing (in Chinese).

Zhao, J.C., 1992. Economics in the Dry-Hot Valleys Region. Economic Press, Hong Kong (in Chinese).

Zhou, L.L., Yang, B., Xue, N.D., Li, F.H., Seip, M., Cong, X., Yan, Y.Z., Liu, B., Han, B.L., Li, H.Y., 2014. Ecological risks and potential sources of heavy metals in agricultural soils from Huanghuai Plain, China. Environ. Sci. Pollut. Res. 21, 1360-1369.

Zimmerman, D.L., Zimmerman, M.B., 1991. A comparison of spatial semivariogram estimators and corresponding ordinary kriging predictors. Technometrics 33 (1), 77-91. 